\title{
In vitro combination characterization of the new anticancer plant drug $\beta$-elemene with taxanes against human lung carcinoma
}

\author{
JINSHUN ZHAO ${ }^{1 *}$, QINGDI Q. LI $^{2 *}$, BAOBO ZOU ${ }^{1}$, GANGDUO WANG $^{1}$, XIPING LI ${ }^{1}$, JEE EUN KIM ${ }^{1}$, \\ CHRISTOPHER F. CUFF ${ }^{1}$, LAN HUANG $^{3}$, EDDIE REED ${ }^{4}$ and KEVIN GARDNER ${ }^{2}$ \\ ${ }^{1}$ Mary Babb Randolph Cancer Center and Department of Microbiology, Immunology and Cell Biology, Robert C. Byrd \\ Health Sciences Center, West Virginia University, Morgantown, WV 26506; ${ }^{2}$ Laboratory of Receptor Biology and Gene \\ Expression, Center for Cancer Research, National Cancer Institute, National Institutes of Health, Bethesda, MD 20892; \\ ${ }^{3}$ HYWE Pharmaceutical Corporation, 426 Mountain Avenue, Berkeley Heights, NJ 07922; ${ }^{4}$ Division of Cancer \\ Prevention and Control, Centers for Disease Control and Prevention, Atlanta, GA 30341, USA
}

Received March 6, 2007; Accepted April 26, 2007

\begin{abstract}
P.R. China as a novel antitumor plant drug isolated from the Chinese medicinal herb Zedoary. To explore potentially useful combinations of $\beta$-elemene with taxanes in the clinic, we characterized the effects of ß-elemene combined with taxanes in human lung cancer cells using a median effect analysis, micronucleus assay, apoptotic detection, and determination of gene expression in the signaling pathways of apoptosis. The synergistic analysis indicated that the interactions of $ß$-elemene with paclitaxel or docetaxel ranged from slight synergism to synergism. Combinations of $\beta$-elemene with docetaxel induced much stronger synergistic interactions in p53 mutant $\mathrm{H} 23$ cells and p53 null $\mathrm{H} 358$ cells than in p53 wild-type H460 and A549 cells. Similar synergistic interactions were observed by micronucleus assay, apoptotic detection, and determination of apoptotic gene expression. Our findings indicate that the synergistic effects achieved with combinations of $\beta$-elemene and taxanes are related to the augmented cytotoxic efficacy of taxanes owing to the action of B-elemene. In H460 and A549 cells, dose-dependent upregulation of p53 protein expression was observed in cultures treated with docetaxel alone and with docetaxel plus $\beta$-elemene, whereas no significant change in p53 expression was observed in any of the treatment groups in H23 cells. Fas revealed no alteration of expression with any of the treatments in this study. However, the combination
\end{abstract}

Correspondence to: Dr Qingdi Quentin Li, Laboratory of Receptor Biology and Gene Expression, Center for Cancer Research, National Cancer Institute, National Institutes of Health, Bethesda, MD 20892, USA

E-mail: liquenti@mail.nih.gov

${ }^{*}$ Contributed equally

Key words: B-elemene, taxane, combination index, synergism, apoptosis, drug resistance, lung cancer treatments induced increased cytochrome c release from mitochondria, significant caspase- 8 and -3 cleavage, and downregulation of $\mathrm{Bcl}-2$ and $\mathrm{Bcl}-\mathrm{X}_{\mathrm{L}}$ expression. These results suggest that, although p53 plays an important role in taxaneinduced cell death, apoptosis induced by ß-elemene or in combination with docetaxel thereof seems to be initiated through a p53- and Fas-independent pathway via mitochondria in our lung cancer cells. The suppression of specific 'survival' gene expression appears to be the key action leading to the synergistic effect of combination treatments with $\beta$-elemene and taxanes. Finally, the $\beta$-elemene-induced alteration of cell membrane permeability, which has potential to result in enhanced cellular uptake of taxanes, may also contribute to the synergistic interactions of the combination treatments.

\section{Introduction}

Lung cancer is the leading cause of cancer death in both men and women in the United States, killing more people than breast, prostate, colon, and pancreas cancers combined. More than one million people worldwide are diagnosed with lung cancer every year. Taxanes, which are antimitotic drugs, have been widely used clinically for chemotherapy of patients with lung cancer in recent years. Like other antimitotic agents, taxanes have undesired side effects that can be serious. The most common side effects are neutropenia, alopecia, allergic reactions, neuropathy, and fatigue (1). Drug resistance to taxanes represents another major obstacle when these drugs are used alone as single clinical agents. The use of two taxanes, paclitaxel and docetaxel, in combination with other anticancer drugs, such as anthracyclines, antimetabolites, alkylating agents, and topoisomerase inhibitors, is being studied for the treatment of human cancers (1). Interest in the combination of taxanes with other anticancer drugs has been profound because these anticancer drugs may have non-overlapping side effect profiles and may be able to overcome some of the resistance of cancers to taxanes as single agents (2).

Taxanes usually target the tubulin/microtubule network of the cytoskeleton, which is formed by an assembly of cytoplasmic tubulin dimers. Several synthetic and natural 
compounds interact specifically with tubulin and microtubules, fundamentally destroying their dynamic character and leading to cell death (3). In cancer treatment, taxanes are the most commonly used of the antimitotic drugs, which are an important class of antitumor drugs that inhibit the functions of cellular microtubules by suppressing their dynamics. They are potent inhibitors of cell growth and cell cycle progression, and induce apoptotic cell death (4). The two clinical taxane prototypes, paclitaxel and docetaxel, are widely used as components of chemotherapies for ovarian and breast carcinomas and have shown efficacy against a large number of other solid tumors, including carcinomas of the lung, head and neck, bladder, and esophagus $(5,6)$. Paclitaxel (brand name, Taxol) was approved by the Food and Drug Administration (FDA) in 1992 to treat advanced (metastatic) breast cancer (7). Docetaxel (brand name, Taxotere) is a cancer drug that resembles paclitaxel in chemical structure and received FDA approval in 1996 for the treatment of advanced breast cancer in patients who do not respond well to chemotherapy with the drug doxorubicin (7). Although differences exist in their molecular pharmacology, pharmacokinetics, and pharmacodynamic profiles, paclitaxel and docetaxel share similar mechanisms of antitumor action; i.e., the promotion of microtubule assembly and the inhibition of microtubule disassembly. Randomized clinical trials evaluating paclitaxel and docetaxel in the first-line treatment for lung cancers have confirmed that taxanes are leading contributors to the armamentarium of lung cancer treatments (8). In addition to its efficacy in the first-line therapy for non-small cell lung cancer (NSCLC), docetaxel is also the FDA-approved second-line agent for recurrent or relapsed NSCLC in the US (9).

B-elemene, isolated from the Chinese medicinal herb Zedoary, was shown to exhibit in vitro and in vivo antitumor activity to human and murine tumor cells (10). Recent study has shown that this new anticancer drug has substantial clinical activity against various tumors and may present fewer and differential side effects as compared with those of rationally designed anticancer drugs. Several studies have indicated that the possible side effects of $\beta$-elemene given intravenously include slight fever (usually lower than $38^{\circ} \mathrm{C}$ ), gastro-intestinal reactions, allergic reactions, local pain, and phlebitis $(10,11)$. No bone marrow, liver, cardiac, or renal toxicities were found to be related to clinical treatment with ß-elemene (12). However, the mechanisms by which the novel anticancer drug B-elemene leads to cell death and drug sensitivity/resistance are still not clear. Recent studies showed that B-elemeneinhibited cell proliferation was correlated to G2-M phase arrest in leukemia HL-60 and K562 cells $(13,14)$. In addition, B-elemene was found to trigger apoptosis in glioma SHG-44 cells and leukemia K562 cells $(13,15-17)$, and the apoptosis induced by 3 -elemene was associated with reduction of Bcl-2 protein expression. We also showed that the antitumor effect of $ß$-elemene in non-small-cell lung cancer cells is mediated through induction of cell cycle arrest and apoptotic cell death (18). Furthermore, we demonstrated for the first time that Belemene markedly enhanced cisplatin-induced cytotoxicity in chemoresistant ovarian carcinoma cells (19). The effect and mechanism of B-elemene in combination with other chemotherapeutic agents for malignancies are not elucidated, however, investigations have revealed differences in cell toxicity in vitro and side effects in vivo between B-elemene and taxanes that suggest they may be suitable for use in combination.

In the present article, the in vitro cytotoxicities of $B$ elemene, paclitaxel, and docetaxel were evaluated in two-drug combinations using four human lung cancer cell lines, which included p53 wild-type H460 and A549 cells, p53 mutationtype $\mathrm{H} 23$ cells, and p53 null-type $\mathrm{H} 358$ cells. The aim of this study was to address the issue of synergism between $\beta$ elemene and taxanes in their effects against human lung cancer. Our results indicate that the interaction effects of $\beta$-elemene with paclitaxel or docetaxel in the four lung cancer cell lines examined ranged from slight synergism to synergism. The combinations of B-elemene with taxane exerted much stronger synergistic interactions in p53 mutation-type $\mathrm{H} 23$ and 553 null-type $\mathrm{H} 358$ cells than in p53 wild-type $\mathrm{H} 460$ and A549 cells. Furthermore, our findings indicate that the ability to achieve synergistic effects by the concomitant use of $\beta$ elemene and taxane may be related to taxane-induced inhibition of the expression of drug resistance genes. The alteration of cell membrane permeability induced by B-elemene, which has potential to result in an enhanced cellular intake of taxane, may also play an important role in the synergistic interactions of the combination treatments. Finally, our data indicate a new chemotherapy strategy of taxane treatment in combination with $\beta$-elemene that has potential clinical impact against lung cancer. Therefore, the combination of ß-elemene with paclitaxel or docetaxel presently being evaluated in vitro should also be evaluated in a clinical setting.

\section{Materials and methods}

Chemicals and reagents. Paclitaxel, docetaxel, propidium iodide (PI), and the mitochondria isolation kit were purchased from Sigma Aldrich Company (St. Louis, MO). The MTT assay kit (CellTiter 96 AQueous One Solution Cell Proliferation Assay) was obtained from Promega Corp. (Madison, WI). ß-elemene was provided by Dalian Yuanda Pharmaceutical Co. Ltd. (Dalian, P.R. China). Annexin V-FITC was obtained from Caltag Laboratories (Burlingame, CA). Antibodies were supplied by Santa Cruz Biotechnology Inc. (Santa Cruz, CA), if not otherwise mentioned.

The following stock solutions were prepared and stored at $-70^{\circ} \mathrm{C}$ : paclitaxel $(1 \mathrm{mM})$, docetaxel $(1 \mathrm{mM})$, and $\beta$-elemene (4.89 $\mathrm{mM}$ ) dissolved in dimethyl sulfoxide (DMSO) and diluted in RPMI-1640 medium. The stock solutions were further diluted in the culture medium to achieve the desired drug concentrations before use.

Cell lines and cell culture conditions. Human lung cancer cell lines p53 wild-type H460 and A549, p53 mutation-type H23, and p53 null-type $\mathrm{H} 358$ were purchased from American Type Culture Collection (ATCC, Manassas, VA). RPMI-1640 medium (Life Technologies, Inc.) was used for cell culture growth. Prior to the experiment, the cells were kept in logarithmic growth in $75-\mathrm{cm}^{2}$ cell culture flasks by passing the cells every third day using RPMI-1640 medium, which contained $2 \mathrm{mM}$ L-glutamine, $100 \mathrm{U} / \mathrm{ml}$ streptomycin, $100 \mathrm{U} /$ $\mathrm{ml}$ penicillin, and $10 \%(\mathrm{v} / \mathrm{v})$ heat-inactivated fetal bovine serum. The cells were grown at $37^{\circ} \mathrm{C}$ in a humidified atmosphere of $5 \% \mathrm{CO}_{2}$ and $95 \%$ air. Cells in mid-logarithmic growth 
(50\% confluence) were used for the experiments. The cultures were repeatedly evaluated for the presence of mycoplasma and had viability $>95 \%$.

MTT assay. The toxic efficacy of each drug was evaluated individually by MTT assay in each of the four lung cancer cell lines. The cells were harvested during logarithmic growth and were seeded at 1,000 cells/well in $100 \mu 1$ medium in 96well flat-bottomed microtiter plates. After the cells attached overnight, the medium was discarded, and the cells were incubated with or without drug treatment for the designated times. At 24,48 , or $72 \mathrm{~h}$ after treatment, $20 \mu \mathrm{l}$ of MTT assay solution was added to each well. After a 2-h incubation in a $37^{\circ} \mathrm{C}$ incubator, the absorbance at $690 \mathrm{~nm}$ was measured using a microplate reader (Thermo Labsystems, VA) to determine the survival percentage. Eight replica wells were measured for each treatment group, and each experiment was repeated three times. Appropriate solvent controls were run with the assays and produced no cytotoxic effects. The data were analyzed by converting the dose-response curves into log-linear model regression curves. The $50 \%$ inhibitory concentrations $\left(\mathrm{IC}_{50}\right.$, i.e., the drug concentration causing $50 \%$ inhibition of cell viability) for each drug alone and in combinations were determined from the plots of the percentage growth inhibition versus the log of the drug concentration (linear regression) by comparison with untreated cells. All reported values are the means of three experiments, with each study having eight wells per dose level.

Micronucleus assay. Cells were seeded in a cell culture dish $(100 \times 20 \mathrm{~mm})$ into which a sterilized glass slide $(18 \times 18 \mathrm{~mm})$ had been placed before seeding. After treatment in the presence or absence of ß-elemene, paclitaxel, docetaxel, or the combinations of two drugs according to the desired method, the cells were gently rinsed with PBS for $2 \mathrm{~min}$. The cells were incubated in a hypotonic solution containing $0.075 \mathrm{M} \mathrm{KCl}$ for 4-8 min and then fixed with a solution of methanol and glacial acetic acid $(3: 1, \mathrm{v} / \mathrm{v})$ for $1 \mathrm{~h}$. The cells were stained with TREND Giemsa Plus stain (Alexon Treny, Ramsey, MN) following the manufacturer's protocol and examined under light microscopy. At least 1,000 cells per slide were scored for the frequency rate of micronuclei $(\mathrm{MN})$. At the same time, 300 nuclei were counted for the analysis of mitotic cell frequency. In addition, photographs were taken under the microscope for the observation of morphological changes.

Annexin $V$ binding assay. Cell culture was conducted as stated above. After the desired treatments, the cells were transferred from a culture flask to a staining tube and were washed with $4 \mathrm{ml}$ of PBS at $4^{\circ} \mathrm{C}$. The cells were centrifuged for $4 \mathrm{~min}$ at $1,000 \mathrm{rpm}$ at $4^{\circ} \mathrm{C}$, and the supernatants were discarded. One hundred $\mu \mathrm{l}$ of annexin V-FITC $(2 \mu \mathrm{g} / \mathrm{ml})$ in annexin $\mathrm{V}$ binding buffer (10 mM HEPES, $150 \mathrm{mM} \mathrm{NaCl}$, $5 \mathrm{mM} \mathrm{KCl}, 1 \mathrm{mM} \mathrm{MgCl}, 1.8 \mathrm{mM} \mathrm{CaCl}_{2}, \mathrm{pH}$ 7.4) were added to the cells, and the staining tubes were incubated for $1.5 \mathrm{~h}$ on ice in the dark. PI ( $0.2 \mu \mathrm{g}$ dissolved in PBS) was added to each tube, and the cells were incubated for $20 \mathrm{~min}$. Subsequently, the cells were washed with $4 \mathrm{ml}$ HEPES buffer and were analyzed by flow cytometry within $30 \mathrm{~min}$. All data were acquired with a Becton-Dickinson FACSCalibur dual laser cytometer. The data analysis was performed with the CellQuest Pro program (Becton-Dickinson). The number of apoptotic cells is expressed as a percentage of the total number of events.

Western blot analysis. Cells with or without treatment were washed with $4^{\circ} \mathrm{C}$ PBS and were lysed on ice for $40 \mathrm{~min}$ in cell lysis buffer (Cell Signaling Technology, Inc., Beverly, MA) freshly supplemented with $10 \mu \mathrm{g} / \mathrm{ml}$ phenylmethylsulfonyl fluoride and $20 \mu \mathrm{M}$ aprotinin before use. After the lysate was cleared by centrifugation at 12,000 rpm for $20 \mathrm{~min}$ at $4^{\circ} \mathrm{C}$, the total protein concentration of the whole-cell lysate was determined using Bio-Rad protein assay solution. Cytoplasmic lysates and mitochondrial lysates were prepared as described by Eminel et al (20). Fifty $\mu \mathrm{g}$ of whole-cell lysate, cytoplasmic lysate, or mitochondrial lysate were denatured in $15 \mu 1$ of $2 \mathrm{X}$ SDS sample loading buffer for $8 \mathrm{~min}$ at $95^{\circ} \mathrm{C}$, separated on $10 \%$ SDS-PAGE gels, and electrotransferred to a nylon transfer membrane by semi-dry electrophoretic transfer. After nonspecific binding sites were blocked with 5\% skim milk in PBS containing $0.05 \%$ Tween-20 (PBST) overnight at $4{ }^{\circ} \mathrm{C}$, the membranes were incubated in the relevant primary antibody (diluted 1:200-500 with $2.5 \%$ skim milk in PBST) for $2 \mathrm{~h}$ at room temperature. After washing with PBST eight times for $20 \mathrm{~min}$ each, the membranes were incubated in $2.5 \%$ skim milk in PBST containing the appropriate second antibody $(1: 2000)$ at room temperature for $1 \mathrm{~h}$ with constant shaking. The target proteins were detected using the ECL protein detection kit (Amersham Biosciences) and were visualized by autoradiography with Kodak BioMax Light film (Fisher Scientific). For the normalization of protein loading, the same membranes were stripped by incubation in stripping buffer $(0.05 \%$ Tween, $0.2 \mathrm{M}$ glycine, $\mathrm{pH} 2.5)$ at $80^{\circ} \mathrm{C}$ for $25 \mathrm{~min}$ and used for Western blotting with a monoclonal antibody against $\beta$-actin (1:500), using the same procedure.

Data analysis. Chemosensitivity was expressed as the $\mathrm{IC}_{50}$ value. The $\mathrm{IC}_{50}$ values were obtained from dose-response curves after fitting the data by log linear regression. The difference between the values of the different groups was evaluated by Student's t-test. The statistical significance of differences was set at $\mathrm{P}<0.05$.

\section{Results}

$I C_{50}$ value of each drug determined individually by MTT assay. Before studying the effects of ß-elemene combined with paclitaxel or docetaxel, the $\mathrm{IC}_{50}$ for each individual drug was evaluated. Dose-response and time-dependent studies for each individual drug were conducted after 24-, 48- and 72-h incubations at different concentrations respectively. The $\mathrm{IC}_{50}$ values for $\beta$-elemene, paclitaxel, and docetaxel at three different time points in four different human lung cancer cell lines were calculated from the MTT assay results. Each of the three anticancer drugs inhibited the growth of lung cancer cells (Table I; Fig. 1A, B and C). B-elemene was less toxic than paclitaxel or docetaxel under the same experimental conditions in each of the four lung cancer cell lines. With increasing $\beta$-elemene concentration or prolonged incubation time, the 
Table I. $\mathrm{IC}_{50}$ values of $\beta$-elemene, paclitaxel, and docetaxel examined in four human lung cancer cell lines as evaluated by the MTT assay.

\begin{tabular}{|c|c|c|c|c|}
\hline \multirow[b]{2}{*}{ Treatment } & \multirow[b]{2}{*}{ Cell line } & \multicolumn{3}{|c|}{$\mathrm{IC}_{50}$} \\
\hline & & $24 \mathrm{~h}$ & $48 \mathrm{~h}$ & $72 \mathrm{~h}$ \\
\hline \multirow[t]{4}{*}{ B-elemene $(\mu \mathrm{M})$} & A549 & 398.9 & 261.9 & 221.5 \\
\hline & $\mathrm{H} 460$ & 390.8 & 336.6 & 275.6 \\
\hline & $\mathrm{H} 23$ & 367.0 & 279.9 & 239.1 \\
\hline & H358 & 390.6 & 312.5 & 254.8 \\
\hline \multirow[t]{4}{*}{ Paclitaxel (nM) } & A549 & $>1280.0^{\mathrm{a}}$ & 19.8 & 9.5 \\
\hline & $\mathrm{H} 460$ & $>1280.0^{\mathrm{a}}$ & 10.6 & 6.3 \\
\hline & $\mathrm{H} 23$ & $>1280.0^{\mathrm{a}}$ & $>1280.0^{\mathrm{a}}$ & 438.6 \\
\hline & H358 & $>1280.0^{\mathrm{a}}$ & $>1280.0^{\mathrm{a}}$ & 520.0 \\
\hline \multirow[t]{4}{*}{ Docetaxel (nM) } & A549 & $>1280.0^{\mathrm{a}}$ & 24.3 & 6.6 \\
\hline & $\mathrm{H} 460$ & $>1280.0^{\mathrm{a}}$ & 3.3 & 2.3 \\
\hline & $\mathrm{H} 23$ & $>1280.0^{\mathrm{a}}$ & $>1280.0^{\mathrm{a}}$ & 214.5 \\
\hline & H358 & $>1280.0^{\mathrm{a}}$ & $>1280.0^{\mathrm{a}}$ & 367.2 \\
\hline
\end{tabular}

$\mathrm{IC}_{50}$ value is the concentration of drug required to inhibit cell growth by $50 \%$ relative to dilute controls; presented as the mean of eight simultaneous replicates repeated three times. The $\%$ cell viability $=$ (OD with drug - blank) / (OD without drug - blank) x 100. ${ }^{a}$ Values listed as $>1280.0 \mathrm{nM}$ paclitaxel or docetaxel indicate that the $\mathrm{IC}_{50}$ values were not detectable in the treated lung cancer cells.

percentage of cell viability decreased in a dose-response and time-dependent manner. No obvious difference was observed in the $\mathrm{IC}_{50}$ value for $\beta$-elemene among the different lung cancer cell lines. However, a marked difference was seen in cytotoxic susceptibility among the cell lines when the cells were treated with paclitaxel or docetaxel. The p53 mutationtype $\mathrm{H} 23$ cells and p53 null-type $\mathrm{H} 358$ cells revealed much stronger resistance to the toxicity of taxanes than did the p53 wild-type H460 and A549 cells. Importantly, although all of the lung cancer cells were sensitive to the cytotoxicity of paclitaxel or docetaxel at lower concentrations, all four lung cancer cell lines presented drug resistance at elevated paclitaxel or docetaxel concentrations, especially $>80.0 \mathrm{nM}$. For instance, after $72 \mathrm{~h}$ at $1280.0 \mathrm{nM}$ paclitaxel or docetaxel, all four lung cancer cell lines still exhibited $>10 \%$ cell viability.

Effects of drug combinations evaluated by synergistic analysis. To determine the precise nature of the effects of $\beta$-elemene combined with paclitaxel or docetaxel, a combination index (CI) for both mutually exclusive and mutually non-exclusive drugs, as defined by Chou and Talalay (21), was calculated after a 72-h treatment of the four human lung cancer cell lines (Table II). Ten fixed drug combinations with the concentrations of each drug at values above and below its $\mathrm{IC}_{50}$, i.e., within a range of $0.1-2 \mathrm{~N}$ where $\mathrm{N}$ is a value near the $\mathrm{IC}_{50}$ of each drug individually, were explored. The dose-effect curves were plotted for each drug and for the ten diluted, fixed-ratio combinations. The combination index $(\mathrm{CI})$ was then determined
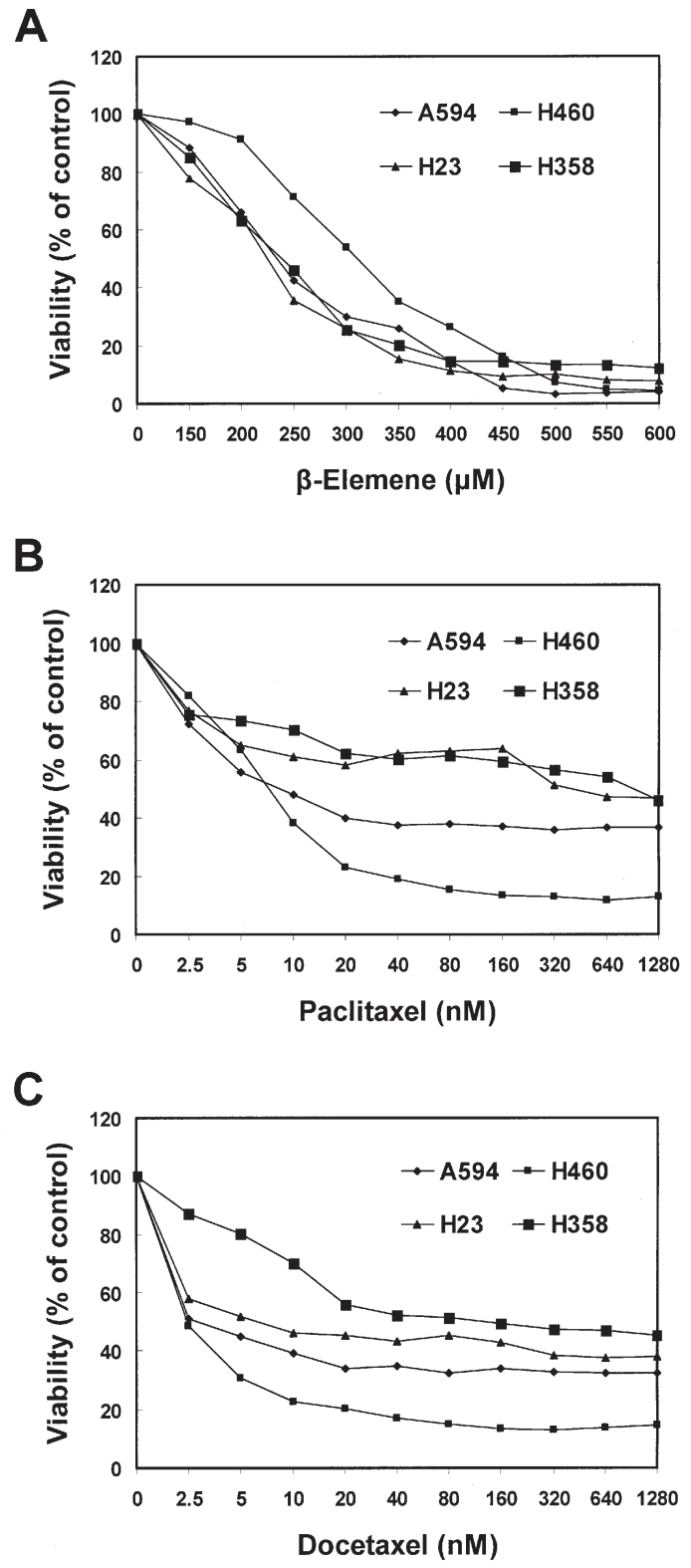

Figure 1. Effects of $ß$-elemene, paclitaxel, or docetaxel on in vitro cytotoxicity in four human lung cancer cell lines determined by MTT assay. p53 wild-type cells (H460 and A549), p53 mutation-type cells (H23), and p53 null-type cells (H358) were evenly distributed in 96 -well plates $\left(5 \times 10^{3}\right.$ per well) and treated with different concentrations of $\beta$-elemene (A), paclitaxel (B), or docetaxel (C) for 24, 48 and $72 \mathrm{~h}$ (data at 24 and $48 \mathrm{~h}$ not shown). Each concentration was run in triplicate. The ability of the drugs to inhibit cell proliferation was determined by the MTT cell survival assay, as described in Materials and methods, and cell viability values were expressed relative to those wells where no drug was added ( $100 \%$ control value). The results represent the mean of at least three independent experiments.

using the equations for i) mutually exclusive or ii) nonexclusive drugs as follows (22) (El., elemene; Tax, taxane; comb., combined):

i)

$\mathrm{CI}=\frac{\mathrm{IC}_{50} \text { El. comb. }}{\mathrm{IC}_{50} \text { El. alone }}+\frac{\mathrm{IC}_{50} \text { Tax. comb. }}{\mathrm{IC}_{50} \text { Tax. alone }}$

ii) $\mathrm{CI}=\frac{\mathrm{IC}_{50} \text { El. comb. }}{\mathrm{IC}}+\frac{\mathrm{IC}_{50} \text { Tax. comb. }}{\mathrm{IC} \text { Ta }}+\frac{\mathrm{IC}_{50} \text { El. comb. }}{\mathrm{IC}_{50} \text { Tax. comb. }}$ 
Table II. Synergistic analysis of the effects of $\beta$-elemene combined with paclitaxel or docetaxel in human lung cancer cell lines after a 72-h treatment. ${ }^{\mathrm{a}}$

\begin{tabular}{lccc}
\hline Cell line & $\begin{array}{c}\text { Drug combination } \\
\text { of } \beta \text {-elemene with }\end{array}$ & $\begin{array}{c}\mathrm{CI}^{\mathrm{b}} \\
(\text { mean } \pm \mathrm{SD})\end{array}$ & $\begin{array}{c}\mathrm{CI}^{\mathrm{c}} \\
(\text { mean } \pm \mathrm{SD})\end{array}$ \\
\hline A549 & Paclitaxel & $0.70 \pm 0.03$ & $0.86 \pm 0.06$ \\
& Docetaxel & $0.74 \pm 0.06$ & $0.88 \pm 0.08$ \\
$\mathrm{H} 460$ & Paclitaxel & $0.78 \pm 0.15$ & $0.89 \pm 0.14$ \\
& Docetaxel & $0.66 \pm 0.09$ & $0.76 \pm 0.11$ \\
$\mathrm{H} 23$ & Paclitaxel & $0.44 \pm 0.06$ & $0.48 \pm 0.09$ \\
& Docetaxel & $0.49 \pm 0.09$ & $0.55 \pm 0.06$ \\
$\mathrm{H} 358$ & Paclitaxel & $0.49 \pm 0.07$ & $0.54 \pm 0.05$ \\
& Docetaxel & $0.67 \pm 0.09$ & $0.78 \pm 0.07$ \\
\hline
\end{tabular}

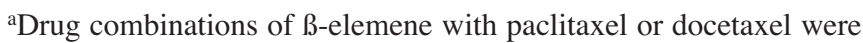
evaluated in four human lung cancer cell lines. CI values are shown for $\mathrm{Fa} 50$ ( $\mathrm{Fa}$ is the fraction of cells affected; $\mathrm{Fa} 50$ is the point at which $50 \%$ of the cells were inhibited). Data are means \pm SD of three independent experiments for each cell line. ${ }^{\mathrm{b}} \mathrm{CI}$ values calculated as for mutually exclusive drugs. ${ }^{\mathrm{c}} \mathrm{CI}$ values calculated as for mutually non-exclusive drugs.

Generally, it is considered that a CI value $<1.0$ indicates synergism, $\mathrm{CI}=1.0$ indicates an additive effect, and $\mathrm{CI}>1.0$ indicates antagonism. However, the more conservative classification method of Soriano et al (23), which takes into account the confidence interval or standard division of the CI values, classifies the effects of drug combinations according to $\mathrm{CI}$ values as follows: $>1.3$, antagonism; 1.1-1.3, moderate antagonism; 0.9-1.1, additive effect; 0.8-0.9, slight synergism; 0.6-0.8, moderate synergism; 0.4-0.6, synergism; and 0.2-0.4, strong synergism.

The effects of $\beta$-elemene combined with paclitaxel or docetaxel at higher levels of cytotoxicity $\left(\right.$ at $\mathrm{IC}_{50}$ ) on the inhibition of human lung cancer cell proliferation are shown in Table II. From these data, it can be concluded that, whether the mechanism of drug interactions was assumed to be mutually exclusive or mutually non-exclusive, the CI values for the combinations of $\beta$-elemene with paclitaxel or docetaxel revealed cytotoxic effects ranging from slight synergism to synergism, even when the CIs were evaluated with the classification method of Martin et al. The synergistic effects of combination interactions were much stronger in p53 mutation-type and p53 null-type cells than in p53 wild-type cells. Furthermore, the CIs for B-elemene with paclitaxel or docetaxel varied depending on the cell type examined. These variations might reflect differences in the way different lung cancer cells handle drug-inflicted damage. However, no obvious differences were noted among the CIs for the combinations of $\beta$-elemene and paclitaxel and those for the combinations of $\beta$-elemene and docetaxel in any of the four cell lines.

Effects of drug combinations evaluated by micronucleus assay. We examined whether the interactions of B-elemene combined with paclitaxel or docetaxel that were revealed by the synergistic analysis could be confirmed by morphological observation by light microscopy. With the micronucleus assay, stronger cytotoxic efficacy was observed in the presence of two-drug combinations than with any of the three drugs individually (Table III, Fig. 2). Our data demonstrated that $ß$-elemene treatment alone did not induce a significant increase

Table III. Micronucleus rate and mitotic interphase frequency in human lung cancer cells after a 48-h treatment with 3 -elemene, paclitaxel, or docetaxel, alone or in two-drug combinations.

\begin{tabular}{|c|c|c|c|c|c|c|}
\hline \multirow[b]{3}{*}{ Treatment } & \multicolumn{6}{|c|}{ Cell line } \\
\hline & \multicolumn{2}{|c|}{ A549 } & \multicolumn{2}{|c|}{$\mathrm{H} 460$} & \multicolumn{2}{|c|}{ H358 } \\
\hline & $\begin{array}{l}\mathrm{MN}^{\mathrm{a}} \\
(\% o)\end{array}$ & $\begin{array}{l}\mathrm{M}^{\mathrm{b}} \\
(\%)\end{array}$ & $\begin{array}{l}\mathrm{MN}^{\mathrm{a}} \\
(\% 0)\end{array}$ & $\begin{array}{l}\mathrm{M}^{\mathrm{b}} \\
(\%)\end{array}$ & $\begin{array}{l}\mathrm{MN}^{\mathrm{a}} \\
(\%)()^{2}\end{array}$ & $\begin{array}{l}\mathrm{M}^{\mathrm{b}} \\
(\%)\end{array}$ \\
\hline Untreated control & 1 & 3 & 0 & 2 & 0 & 2 \\
\hline $100 \mu \mathrm{M}$ ß-elemene & 4 & 20 & 3 & 2 & 0 & 2 \\
\hline 4 nM paclitaxel & 30 & 19 & 6 & 9 & 2 & 6 \\
\hline $2 \mathrm{nM}$ docetaxel & 40 & 18 & 6 & 7 & 30 & 6 \\
\hline $200 \mu \mathrm{M}$ ß-elemene & 3 & 1 & 3 & 2 & 2 & 2 \\
\hline $8 \mathrm{nM}$ paclitaxel & 60 & 49 & 30 & 20 & 50 & 15 \\
\hline $4 \mathrm{nM}$ docetaxel & 80 & 30 & 20 & 23 & 20 & 17 \\
\hline $100 \mu \mathrm{M}$ B-elemene $+4 \mathrm{nM}$ paclitaxel & 50 & 50 & 6 & 24 & 42 & 8 \\
\hline $100 \mu \mathrm{M} \beta$-elemene $+2 \mathrm{nM}$ docetaxel & 120 & 65 & 4 & 28 & 100 & 6 \\
\hline
\end{tabular}

The data are the means of three experiments for each cell line, with three slides per treatment group for each experiment. ${ }^{\mathrm{a}} \mathrm{MN}$ represents the number of cells with micronucleus (or micronuclei) in 1,000 cells counted under the light microscope. ${ }^{b} \mathrm{M}$ represents the number of cells in mitotic interphase in 100 cells counted under the light microscope. 

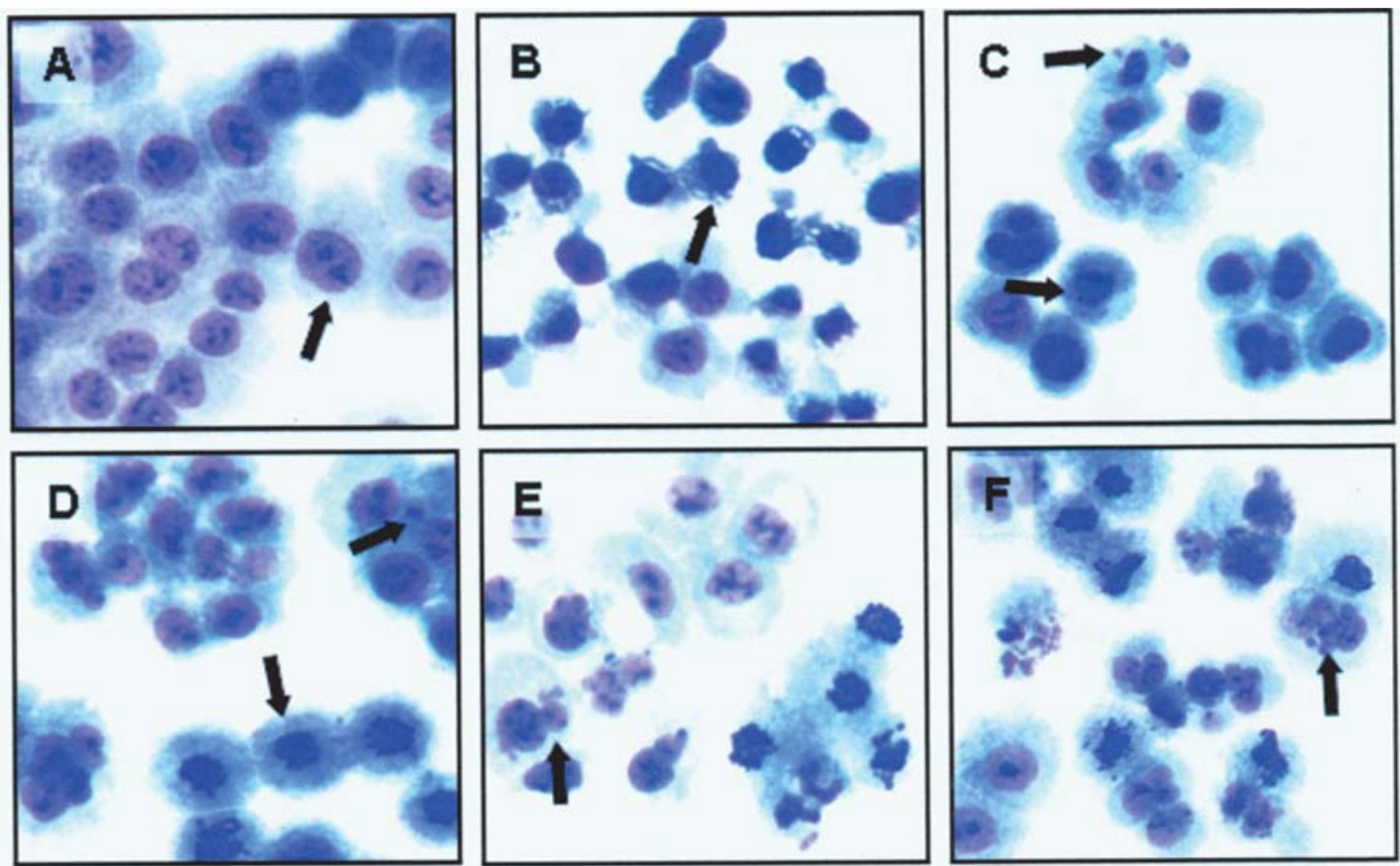

Figure 2. Photomicrograph of the combined effects of B-elemene with paclitaxel or docetaxel in human H460 lung cancer cells after 48-h treatments. A, untreated (control) cells; the arrow shows a normal cell. B, B-elemene $(200 \mu \mathrm{M})$ treatment alone; cells reveal shrinkage and nuclear chromatin condensation (see arrow) which is similar to the morphological changes of cells undergoing apoptosis. C, paclitaxel ( $8 \mathrm{nM})$ treatment alone; the upper arrow shows nuclear damage-related micronucleus (MN) formation; the lower arrow indicates the cell failed to complete mitosis, leading to arrest in a post-mitotic interphase state which hinders the segregation of chromosomes and interferes with nuclear division. These observations are consistent with previous reports that demonstrated cell cycle arrest at G2/M phase. D, docetaxel ( $4 \mathrm{nM})$ treatment alone; the upper arrow shows nuclear damage-related micronucleus formation; the lower arrow indicates a post-mitotic interphase state cell. E, combination of $\beta$-elemene $(100 \mu \mathrm{M})$ and paclitaxel $(4 \mathrm{nM})$ treatment; the arrow shows a multinuclear cell with disassembled and fragmented nuclei, which look like the 'apoptotic bodies' of apoptotic cells. F, combination of B-elemene (100 $\mu \mathrm{M})$ and docetaxel ( $2 \mathrm{nM})$ treatment; the arrow shows a multinuclear cell. These results demonstrate that combination treatments exerted stronger cytotoxic efficacy than did any of the three drugs used individually.

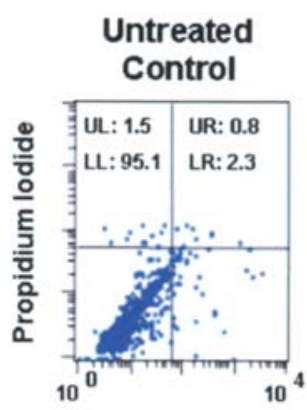

Annexin V-FITC
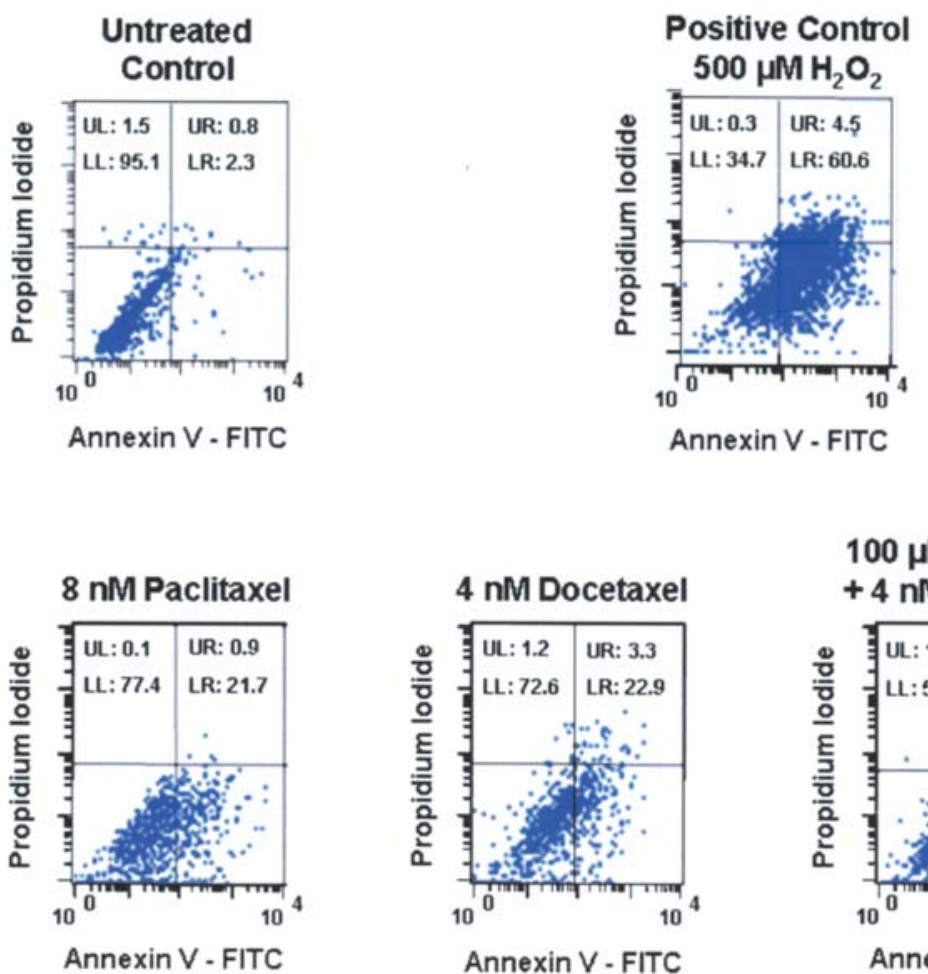

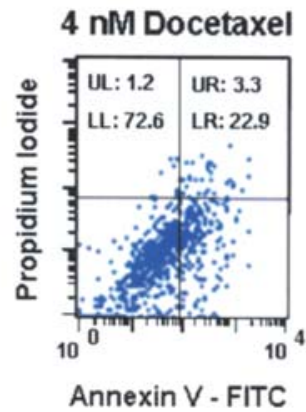

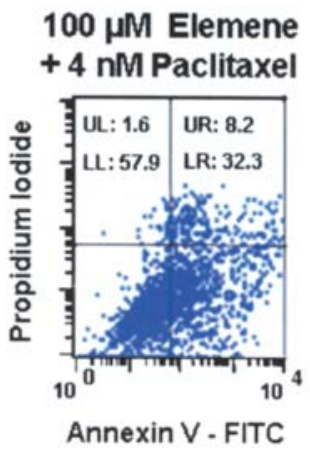

Figure 3. Combination interaction analysis demonstrated by the apoptotic induction of annexin V binding in human H460 lung cancer cells. The cells were treated with $ß$-elemene, paclitaxel, or docetaxel alone, or with two drugs in combination for $48 \mathrm{~h}$. Annexin $\mathrm{V}$ binding assay was carried out using an annexin V-FITC detection kit. Cells induced to undergo apoptosis have two annexin V (AV)-binding subpopulations: single-positive cells (lower right quadrant, LR) that bind AV but not propidium iodide (PI) and double-positive cells (upper right quadrant, UR) that bind both AV and PI. The AV single-positive population is thought to represent an early stage of apoptosis. The double-positive cells represent a late stage of apoptosis or necrosis. The upper left quadrant (UL) shows the PI single-positive cells, which represent a late necrotic stage. The results represent one of three independent experiments. 


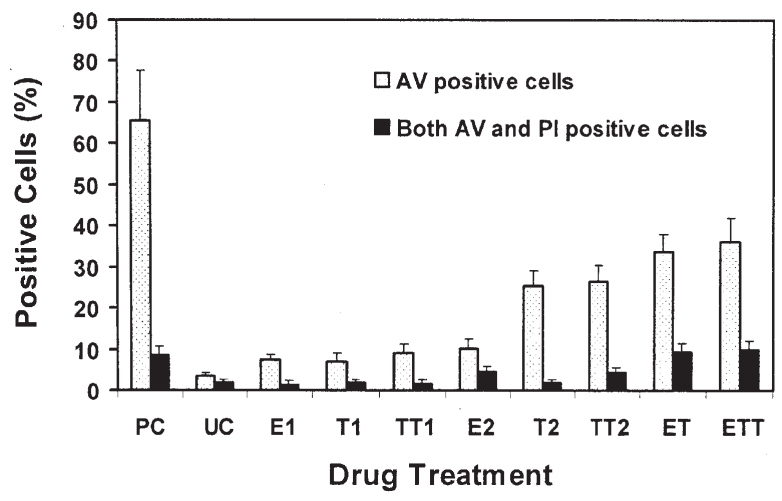

Figure 4. Combination interactions demonstrated by the apoptotic induction of annexin V binding in H460 human lung cancer cells after 48-h treatments with the three studied drugs alone or combinations of two drugs. PC, positive control, induced by $500 \mu \mathrm{M} \mathrm{H}_{2} \mathrm{O}_{2}$; UC, untreated control; E1, $100 \mu \mathrm{M} \beta$ elemene; T1, 4 nM paclitaxel; TT1, 2 nM docetaxel; E2, $200 \mu \mathrm{M}$ B-elemene; T2, $8 \mathrm{nM}$ paclitaxel; TT2, $4 \mathrm{nM}$ docetaxel; ET, $100 \mu \mathrm{M}$ ß-elemene $+4 \mathrm{nM}$ paclitaxel; ETT, $100 \mu \mathrm{M}$ ß-elemene $+2 \mathrm{nM}$ docetaxel. Data represent the statistical results of three independent experiments.

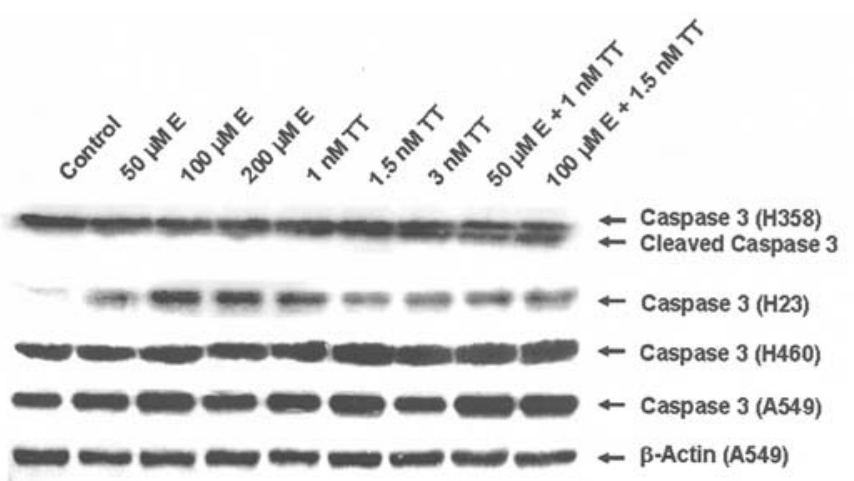

Figure 5. Combination interactions of ß-elemene with docetaxel in apoptotic induction demonstrated by caspase- 3 expression in human lung tumor cells. Cells were exposed to B-elemene or docetaxel alone, or to both agents in combination at the indicated concentrations for $48 \mathrm{~h}$. A total $50 \mu \mathrm{g}$ of cell extract protein isolated from drug-treated cells was subjected to Tris-glycine gel electrophoresis and immunoblotted with the antibody against caspase- 3 . $\beta$-actin was used as a loading control. Western blot data presented are representative of those obtained from three independent experiments. Combination treatments induced the upregulation of procaspase- 3 expression in H23, H460, and A549 cells. In H358 cells, combination treatments induced significant formation of fragments (or cleavage) of caspase-3. Control, untreated; E, ß-elemene; TT, docetaxel.

of the micronucleus rate or the mitotic arrest frequency compared with those of the untreated control $(\mathrm{P}>0.05)$, whereas paclitaxel or docetaxel produced striking increases in these two parameters. Furthermore, after a 48 -h treatment with the drug combinations, especially the combination of $\beta$-elemene and docetaxel, both the micronucleus rate and the mitotic arrest frequency were obviously enhanced compared with the values after each individual drug treatment. Thus, the morphological observations supported the results of the synergistic analysis. These results indicate that $\beta$-elemene induces a significantly increased susceptibility of lung cancer cells to the cytotoxic effects of paclitaxel and docetaxel. This induction might be attributable to increased intracellular uptake of paclitaxel and docetaxel owing to $ß$-elemene, or to increased competition of

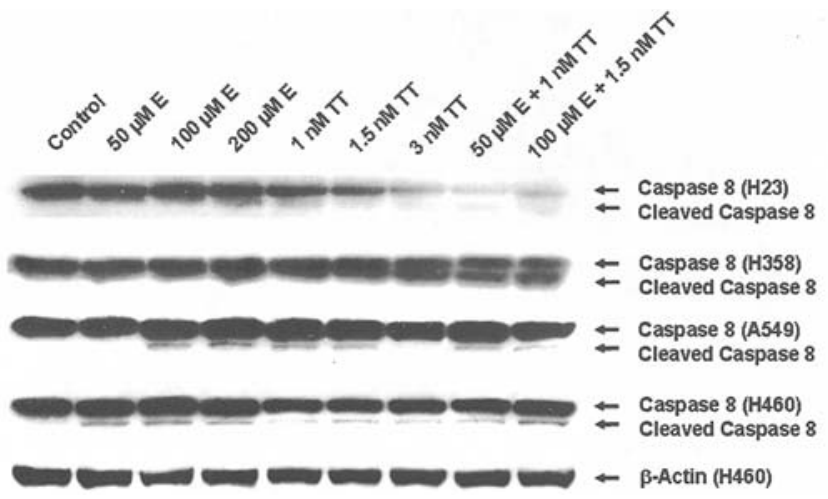

Figure 6. Combination interactions of B-elemene with docetaxel in apoptotic induction demonstrated by caspase- 8 expression in human lung carcinoma cells. Cells were exposed to $ß$-elemene or docetaxel alone, or to both agents in combination at the indicated concentrations for $48 \mathrm{~h}$. A total $50 \mu \mathrm{g}$ of cell extract protein isolated from drug-treated cells was subjected to Tris-glycine gel electrophoresis and immunoblotted with the antibody against caspase-8. $\beta$-actin was used as a loading control. Western blot data presented are representative of those obtained from three independent experiments. In the four human lung cancer cell lines, no significant increase of procaspase- 8 expression is seen in any of the treatment groups; however, in some treatment cultures, the expression of procaspase- 8 shows a striking decrease, which might be caused by the formation of fragments (or cleavage) of caspase- 8 . This phenomenon could be seen more clearly in combination treatment cultures of H23 and H358 cells. Control, untreated; E, B-elemene; TT, docetaxel.

$ß$-elemene for the efflux pump. In addition, in both paclitaxeland docetaxel-treated cultures, we observed a high frequency of cells in mitotic arrest.

Effects of drug combinations demonstrated by apoptotic induction as detected by annexin $V$ binding in human lung cancer cells. The synergistic effect of $\beta$-elemene with paclitaxel or docetaxel after a 48-h treatment was evaluated by apoptotic induction as detected by annexin V binding in H460 cells. Apoptosis was assessed by flow cytometric analysis of cells that were simultaneously stained with annexin V and PI. Flow cytometric analysis showed that a greater percentage of apoptotic cells was induced by treatment with the twodrug combinations ( $\beta$-elemene + paclitaxel or $\beta$-elemene + docetaxel) than with any of the three individually (Figs. 3 and 4). Apoptosis occurred in $38.0 \%$ of cells treated with the combination of $100 \mu \mathrm{M} \beta$-elemene and $2 \mathrm{nM}$ docetaxel, whereas apoptosis occurred in $13.3 \%$ of cells with $200 \mu \mathrm{M}$ B-elemene alone and in $22.9 \%$ of cells with $4 \mathrm{nM}$ docetaxel alone. A similar synergistic effect on apoptotic induction was observed with the combinations of $\beta$-elemene and paclitaxel (Figs. 3 and 4).

Effects of combined treatment with $\beta$-elemene and docetaxel on the expression of proteins involved in apoptotic signal transduction pathways as detected on Western blots. The mechanisms of $\beta$-elemene- and taxane-induced apoptosis are yet to be elucidated. Presently, at least two pathways of caspase activation, extrinsically and intrinsically stimulated cascades, have been delineated in apoptotic processes $(24,25)$. The extrinsic pathway involves apoptosis mediated by cell surface death receptors, such as Fas, tumor necrosis factor receptor, or TRAIL1 receptor. The intrinsic pathway is mediated by the release of cytochrome $\mathrm{c}$ from the mitochondria to the 


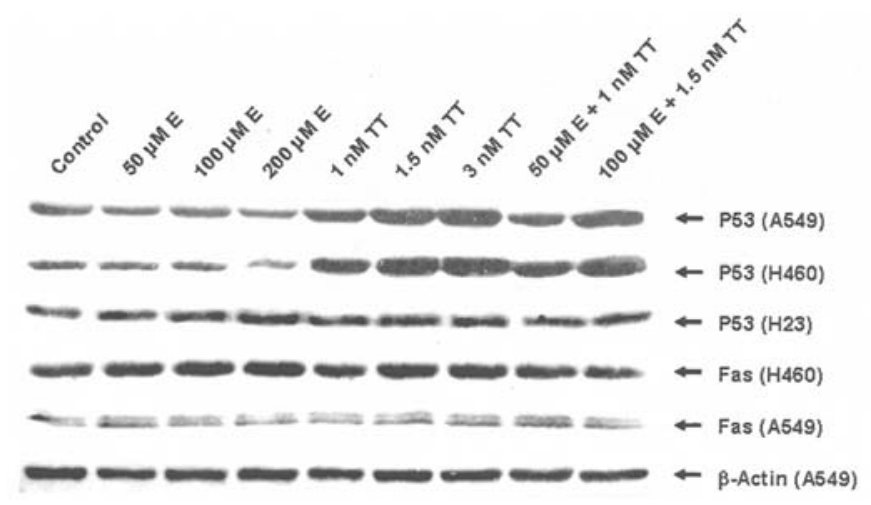

Figure 7. Combination interactions of $\beta$-elemene with docetaxel in apoptotic induction demonstrated by $\mathrm{p} 53$ and Fas expression in human lung tumor cells. Cells were exposed to $\beta$-elemene or docetaxel alone, or to both agents in combination at the indicated concentrations for $48 \mathrm{~h}$. A total $50 \mu \mathrm{g}$ of cell extract protein isolated from drug-treated cells was subjected to Tris-glycine gel electrophoresis and immunoblotted with the antibody against p53 or Fas. $\beta$-actin was used as a loading control. Western blot data presented are representative of those obtained from three independent experiments. Docetaxel induced increased p53 expression in a dose-response manner in the p53 wild-type $\mathrm{H} 460$ and A549 cell lines but not in the p53 mutation-type $\mathrm{H} 23$ line. $\beta$-elemene exerted no obvious effect on 53 expression in any of the human lung cancer cell lines. No significant change in Fas expression is observed with $\beta$-elemene or docetaxel alone or in combination. Control, untreated; E, B-elemene; TT, docetaxel.

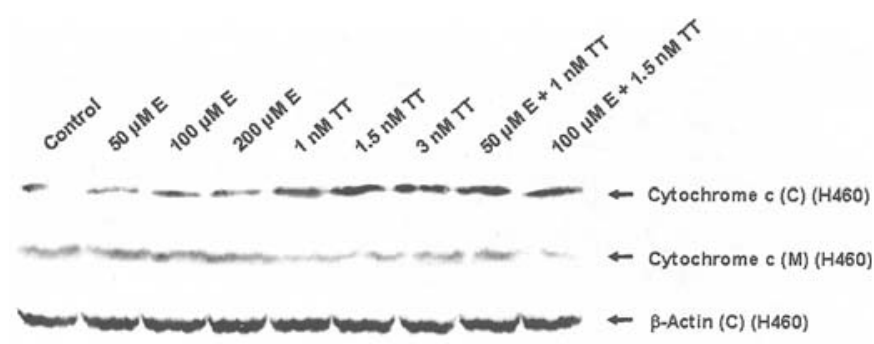

Figure 8. Combination interactions of ß-elemene with docetaxel in apoptotic induction demonstrated by cytochrome c release in human lung cancer $\mathrm{H} 460$ cells. H460 cells were exposed to B-elemene or docetaxel alone, or to both agents in combination at the indicated concentrations for $48 \mathrm{~h}$. A total $50 \mu \mathrm{g}$ of cell extract protein isolated from drug-treated $\mathrm{H} 460$ cells was subjected to Tris-glycine gel electrophoresis and immunoblotted with the antibody against cytochrome c. B-actin was used as a loading control. Western blot data presented are representative of those obtained from three separate experiments. Compared with untreated control cells, H460 cells treated with docetaxel and with drug combinations seem to induce more cytochrome $\mathrm{c}$ release from mitochondria (M) to the cytoplasm (C). Control, untreated; E, ß-elemene; TT, docetaxel.

cytoplasm to initiate a caspase cascade. The two pathways of apoptosis, extrinsic/death receptor and intrinsic/mitochondrial, converge on caspase- 3 and subsequently on other proteases and nucleases that drive the terminal events of programmed cell death (25).

In this study, we found that combination treatments with B-elemene and docetaxel for $48 \mathrm{~h}$ induced the increased cleavage (fragments) of caspase-3 (Fig. 5) and caspase- 8 (Fig. 6). Treatment with ß-elemene, docetaxel, or combinations of these two drugs did not induce the upregulation of Fas expression (Fig. 7). However, a synergistic effect was observed for the release of cytochrome $\mathrm{c}$ from mitochondria to the cytoplasm in combination-treated cells (Fig. 8). The

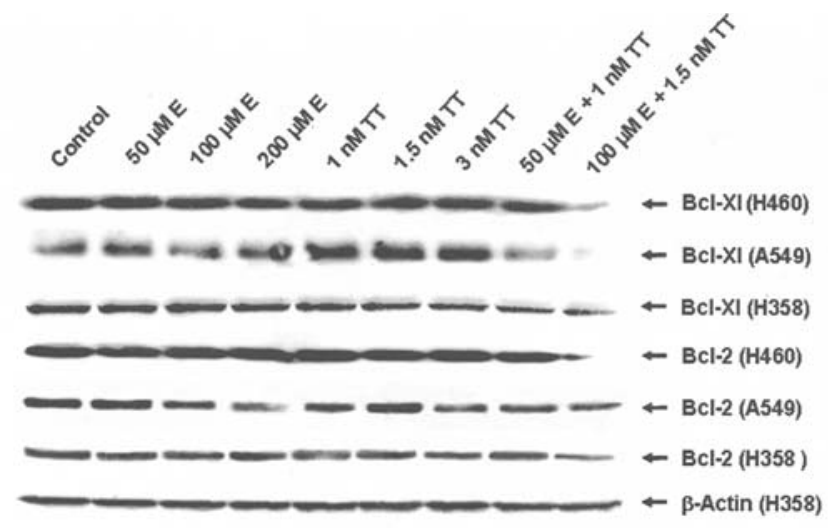

Figure 9. Combination interactions of $\beta$-elemene with docetaxel in apoptotic induction demonstrated by the expression of $\mathrm{Bcl}-2$ and $\mathrm{Bcl}-\mathrm{X}_{\mathrm{L}}$ in human lung carcinoma cells. Cells were exposed to B-elemene or docetaxel alone, or to both agents in combination at the indicated concentrations for $48 \mathrm{~h}$. A total $50 \mu \mathrm{g}$ of cell extract protein isolated from drug-treated cells was subjected to Tris-glycine gel electrophoresis and immunoblotted with the antibody against Bcl-2 or Bcl- $\mathrm{X}_{\mathrm{L}}$. B-actin was used as a loading control. Western blot data presented are representative of those obtained from three independent experiments. Combination treatments of $\beta$-elemene with docetaxel induced significant downregulation of $\mathrm{Bcl}-2$ and $\mathrm{Bcl}-\mathrm{X}_{\mathrm{L}}$ expression, especially at higher-dosage combination treatments. In A549 cells, docetaxel induced the expression of $\mathrm{Bcl}-\mathrm{X}_{\mathrm{L}}$, which is thought to contribute to the occurrence of drug resistance. Control, untreated; E, ß-elemene; TT, docetaxel.

expression of p53 was upregulated in p53 wild-type H460 and A549 cells treated with docetaxel alone and with Belemene plus docetaxel, but not in normal human lung fibroblasts (data not shown) or p53 mutation-type H23 cells (Fig. 7). No alteration of p53 expression was seen in cultures treated with B-elemene alone (Fig. 7). Lastly, the combination treatment with $\beta$-elemene and docetaxel induced significant downregulation of Bcl-2 and Bcl- $\mathrm{X}_{\mathrm{L}}$ expression (Fig. 9).

\section{Discussion}

In this report, we demonstrated that the in vitro interactions of $\beta$-elemene combined with taxanes (paclitaxel or docetaxel) ranged from slight synergism to synergism against human lung cancer cells. There are several important findings in this study. First, we found that synergistic interactions against lung cancer cells existed after the concomitant exposure of the cells to 3 -elemene and a taxane. Stronger synergistic effects occurred in p53 mutation-type and p53 null-type lung cancer cells than in p53 wild-type cells. Second, our results indicated that the mechanisms of apoptotic induction differed between B-elemene and taxanes as they seemed to attack different biochemical targets. $\beta$-elemene probably triggers cancer cell apoptosis processes by interacting with the cell membrane at an early stage, whereas taxanes tend to initiate cell death cascades by interfering with nuclear events. Nevertheless, both $ß$-elemene and taxanes appear to trigger apoptotic induction pathways in a p53- and Fas-independent manner. Third, our results demonstrated significant and dose-dependent enhancement of p53 protein expression in two p53 wild-type lung cancer cell lines treated with taxanes alone and in combination with $\beta$-elemene, whereas no alteration in $\mathrm{p} 53$ protein expression was observed in cells treated with B-elemene at any concentrations. Furthermore, the combination drug treatments induced 
the cleavage of caspase- 8 and -3 as well as significant downregulation of $\mathrm{Bcl}-2$ and $\mathrm{Bcl}-\mathrm{X}_{\mathrm{L}}$. These results indicate that the use of $\beta$-elemene combined with taxanes can enhance apoptotic induction and can inhibit the expression of drug-resistance genes induced by taxanes alone. Apoptotic enhancement induced by combinations of $\beta$-elemene and taxanes may proceed through a death receptor-independent signaling pathway via mitochondria. The alteration of cell membrane permeability induced by $ß$-elemene is also hypothesized to play an important role in the synergistic interactions of the simultaneous exposure to the two drugs because it creates the potential to increase the cellular influx of taxanes. In addition, the enhanced cytotoxicity of taxanes owing to the concomitant exposure with $\beta$-elemene might also reflect competition for the efflux pump between these two chemotherapeutic agents.

Taxanes represent one of the most powerful classes of antitumor agents and have become an integral part of several commonly used chemotherapy regimens in cancer management over the past few years (1). The central cytotoxic activity of taxanes in tumor cells was considered to be the induction of apoptosis $(26,27)$. Although taxanes (paclitaxel and docetaxel) have been shown to be effective for the treatment of lung cancers, taxane-related drug resistance and side effects remain major obstacles to be overcome in clinical practice. As a novel anticancer plant drug in P.R. China, B-elemene has been proven effective for the treatment of cervical carcinoma and cancers of the lung, liver, brain, and other tissues $(12,28)$. The principal side effects of $\beta$-elemene include slight fever, gastrointestinal reactions, allergic reactions, local pain, and phlebitis. An MTT assay analysis of the effect of $\beta$-elemene on the growth of leukemia cells showed that the $\mathrm{IC}_{50} \mathrm{~s}$ in promyelocytic leukemia HL-60 cells and erythroleukemia K562 cells were 135 and $397 \mu \mathrm{M}$, respectively; however, the $\mathrm{IC}_{50}$ in peripheral blood leukocytes (PBL) was $1247 \mu \mathrm{M}$ (29). The inhibitory effect of B-elemene on the proliferation of HL-60 cells was associated with cell cycle arrest at the $S$ to $\mathrm{G} 2 / \mathrm{M}$ phase transition and with the induction of apoptosis. Tumor cell apoptosis induced by ß-elemene was confirmed by DNA ladder formation observed by gel electrophoresis, downregulated $\mathrm{Bcl}-2$ expression $(15,17,29,30)$, and ultrastructural alterations (15). In this regard, B-elemene, a plant anticancer agent with low cellular toxicity to normal tissues, was hypothesized as a possible candidate for a synergistic combination drug with taxanes.

To evaluate the actions against human lung cancer produced by the combination of $\beta$-elemene with paclitaxel or docetaxel, the cytotoxic efficacy of each of the three drugs against human lung tumor cells was first detected individually by MTT assay. Of the three chemotherapeutic agents tested, docetaxel was the most toxic agent to lung carcinoma cells. ß-elemene was less toxic to lung cancer cells than was paclitaxel or docetaxel under the same experimental conditions. No large differences were seen among the $\mathrm{IC}_{50}$ values of $\beta$-elemene in the different lung cancer cell lines. However, striking differences were observed between the cytotoxic susceptibilities of p53 wildtype cells (H460 and A549) and p53 mutant or null cells (H23 and H358) in both the paclitaxel and docetaxel treatment groups. The findings of this study indicate that p53 mutant or null cells (H23 and H358) are much more resistant to the cytotoxicity of paclitaxel or docetaxel, suggesting that the p53 gene plays an important role in the cell death process even though the apoptotic process induced by taxanes might not initiate through a p53-dependent pathway. Interestingly, in this study, we found that all four lung cancer cell lines presented drug resistance to taxanes as drug concentrations increased to $80 \mathrm{nM}$ or higher. These results demonstrate the importance of determining the proper clinical dosage required to produce the greatest chemotherapeutic efficacy while at the same time avoiding the occurrence of drug resistance and minimizing as much as possible the side effects induced by taxane agents.

The median effect model is most accurate at the Fa50 value because it is a linear approximation of a higher order equation (31). Hence, we selected the CI value at the Fa50 as the combination index. Using this methodology, and assuming either mutually exclusive or mutually non-exclusive mechanisms of drug action, virtually all CI values (CIs) from the simultaneous exposure to $ß$-elemene plus either paclitaxel or docetaxel revealed a degree of synergism, which ranged from slight synergism to synergism $(0.4<\mathrm{CI}<0.9)$. The $\mathrm{CIs}$ obtained for simultaneous treatments with $\beta$-elemene and paclitaxel or docetaxel varied in different cell lines but with no significant difference. In addition, no obvious differences were seen among the CIs obtained with the combinations of $\beta$-elemene and paclitaxel or with the combinations of $\beta$-elemene and docetaxel. Although interaction assessments in this study showed that the concurrent exposure to $B$-elemene plus paclitaxel or docetaxel for $72 \mathrm{~h}$ clearly resulted in synergism in all four lung cancer cell lines studied, the molecular mechanism underlying this effect cannot be determined based singly on the synergistic analysis results.

Genetic toxicology tests were among the early studies conducted to assess the safety profile of a compound. They were designed to determine whether a compound can interact with DNA and thereby produce gene mutations or chromosomal breakage. Some tests can also detect compounds that interact with components of the mitotic spindle apparatus. One such frequently used test is the in vitro micronucleus (IVM) test (32). In this study, we used the IVM method to identify morphological changes induced by three antitumor drugs, alone or in combination. Our results indicate that $\beta$ elemene treatment alone did not significantly increase the incidence of micronuclei or mitotic arrest, whereas paclitaxel or docetaxel strikingly increased both parameters. After $48 \mathrm{~h}$ of treatment with the drug combinations, either the rate of micronuclei formation or the percentage of cells in mitotic arrest was significantly enhanced over that seen with each individual drug alone, especially for lung cancer cells treated with combinations of $\beta$-elemene and docetaxel. These results are consistent with those obtained by the synergistic analysis. In addition, in both the paclitaxel- and docetaxel-treated groups, we observed a high frequency of mitotic arrest in the cells. As the present study shows that $\beta$-elemene induces a significantly enhanced susceptibility of lung cancer cells to the cytotoxicity of paclitaxel or docetaxel, we suggest that $\beta$ elemene might produce increased intracellular paclitaxel or docetaxel concentration by inducing increased drug uptake. The enhanced cytotoxicity of taxanes used in combination with ß-elemene might also result from competition for the efflux pump between the two drugs. These mechanisms remain to be elucidated in further studies. 
The detection of annexin $\mathrm{V}$ binding by flow cytometry using a two-color staining regime makes it possible to distinguish cells in early apoptosis, late apoptosis, or necrosis. By detecting annexin $\mathrm{V}$ binding, we found that apoptotic cell numbers could be significantly enhanced in combinationtreated cultures after $48 \mathrm{~h}$ of incubation, which is consistent with the results of the synergistic analysis by the MTT assay and those obtained with the micronucleus assay. Our data indicate that treatment with either $\beta$-elemene and paclitaxel or B-elemene and docetaxel could induce an increase in the number of apoptotic cells, in a dose-dependent manner. Furthermore, the apoptotic cell percentages induced by the treatments with the two-drug combination were greater than those induced by the drugs individually. For example, the combined treatment using $\beta$-elemene $(100 \mu \mathrm{M})$ and docetaxel $(4 \mathrm{nM})$ resulted in apoptosis in $38.0 \%$ of lung cancer cells, whereas $200 \mu \mathrm{M}$ B-elemene or $4 \mathrm{nM}$ docetaxel alone produced apoptosis in $13.3 \%$ and $22.9 \%$ of the cells, respectively. A similar synergistic induction of apoptosis was also observed with the combination of $B$-elemene and paclitaxel. These results suggest that the synergistic cytotoxic effects of the combination of $\beta$-elemene and taxanes might be the result of an enhancement of apoptotic induction.

Two major cellular apoptotic pathways have been documented that mediate apoptosis on exposure to different types of stimuli, such as anticancer drugs, ionizing radiation, and viruses (33). One pathway is the death receptor-dependent signaling pathway triggered by CD95/Fas, the tumor necrosis factor (TNF)-related apoptosis-inducing ligand (TRAIL) receptors, and TNF-receptor-1 (34); the other is the death receptor-independent signaling pathway which acts via the mitochondria $(34,35)$. In both cases, stimulation of the apoptotic pathway leads to the processing and activation of initiator caspases, such as caspase-8, which subsequently transmit the signal to downstream effector caspases. A study by von Haefen et al demonstrated that paclitaxel-induced apoptosis proceeds via a mitochondrial amplification loop driven by caspase- 8 and -3 (36). This caspase-8/3-mediated mitochondrial amplification loop is required for optimal release of cytochrome $\mathrm{c}$, the mitochondrial permeability shift transition, and cell death during apoptosis induced by treatment with the microtubule-damaging agent paclitaxel. Our data are in line with this report. In the present study, we found that B-elemene, docetaxel, or combinations of the two induced an increased cleavage of caspase- 8 and -3 and the release of cytochrome $\mathrm{c}$ from mitochondria into the cytoplasm. Furthermore, significant synergistic effects on these alterations were observed with the combination drug treatments, especially in p53 mutation-type and p53 null-type human lung cancer cells. No alternation of Fas gene expression was observed in our study with B-elemene or docetaxel alone or with a combination of the two drugs. These results are consistent with those of previous studies, demonstrating that taxanes induce apoptosis via a Fas-independent signaling pathway (37-39). The synergistic effects on apoptosis that are induced by combinations of $ß$-elemene and docetaxel seem to occur via a mitochondrial pathway.

Agents that damage DNA, such as anticancer drugs and ionizing radiation, can induce apoptosis through a p53dependent or -independent pathway (40). However, the role of p53 in taxane-induced apoptosis in lung cancer cells remains unclear. In vivo evidence from murine tumor models suggested that the antitumor activity of docetaxel is independent of the tumor suppressor gene p53 (41). The findings derived from our study comparing human lung cancer cells and human lung fibroblasts also imply that cell death induced by taxanes occurs through a p53-independent pathway; i.e., no alteration of p53 expression was observed in human lung fibroblasts treated with different docetaxel concentrations, although the $\mathrm{IC}_{50}$ values and morphological changes were similar to those seen in $\mathrm{H} 460$ and A549 lung cancer cells (data not shown). Although p53 seems to be dispensable for taxane-induced apoptosis (42-44), increased expression of p53 occurs coincidentally with the enhancement of apoptosis in the p53 wild-type cell lines H460 and A549 treated with B-elemene in combination with paclitaxel or docetaxel in our study. Given that taxanes exerted much stronger cytotoxicity in p53 wild-type H460 and A549 cells than in p53 mutation-type H23 cells or p53 null-type H358 cells, our findings suggest that p53 acts at least as a 'promoter' gene in taxane-induced apoptotic cell death. However, the synergistic interaction between $ß$-elemene and docetaxel was not reflected in the expression of $\mathrm{p} 53$, indicating that the synergistic effect of $\beta$-elemene and taxanes is not mediated through a p53-dependent pathway.

Taxanes are important chemotherapeutic agents, but the development of clinical drug resistance poses a major obstacle for the survival of cancer patients. Despite promising initial responses to chemotherapy, many patients experience recurrence of the primary tumor and/or metastases. The mechanisms of resistance to taxanes and other microtubule-stabilizing agents previously characterized in human cell lines include the expression of the drug efflux pump, P-glycoprotein, and mutations in the cellular target of taxane, $\beta$-tubulin (45). In addition, studies have also demonstrated that the overexpression of Bcl-2 and $\mathrm{Bcl}-\mathrm{X}_{\mathrm{L}}$ inhibits taxane-induced Yama protease activity and apoptosis (46-48). Furthermore, Bcl-2 and Bcl- $\mathrm{X}_{\mathrm{L}}$ can also prevent pore formation and block the release of cytochrome c from mitochondria (49). Previous studies indicated that the expression of $\mathrm{Bcl}-2$ was decreased in $\beta$-elemenetreated tumor cells as compared with expression in untreated control cells $(15,29,30)$. Our results indicate that a striking reduction of $\mathrm{Bcl}-2$ and $\mathrm{Bcl}-\mathrm{X}_{\mathrm{L}}$ protein expression was seen only in lung cancer cells exposed to the combination treatments of B-elemene and docetaxel, as compared with expression in cells treated with the drugs individually. Thus, the synergistic effects between $\beta$-elemene and taxanes may be in part related to the $\beta$-elemene-induced downregulation of the expression of the drug resistance genes Bcl-2 and $\mathrm{Bcl}-\mathrm{X}_{\mathrm{L}}$.

In conclusion, side effects and the development of drug resistance limit the use of taxanes for treating patients with lung cancers. In this study, we evaluated treatments with the combination of the new antitumor plant drug $\beta$-elemene and the conventional chemotherapeutic agents paclitaxel and docetaxel in human lung cancer. The combination of $ß$-elemene with paclitaxel or docetaxel resulted in synergistic growth inhibition, especially in the p53 mutation-type and p53 nulltype cell lines. The addition of $\beta$-elemene to taxanes increases the effectiveness of taxanes and may overcome/reverse drug resistance to taxanes. The current study opens up new ways to study the effect of combination interactions of different 
anticancer agents in relation to the apoptotic mechanism activated. Further study is necessary to accurately dissect the interaction mechanisms of these drug combinations. Finally, in addition to the in vitro evaluation of the effects of ß-elemene combined with paclitaxel or docetaxel, these effects should be evaluated in a clinical setting.

\section{Acknowledgments}

We thank Dr Cynthia Cunningham for technical assistance during the FACS measurements. This study was supported by a grant from the National Institutes of Health (no. P20RR16440010003).

\section{References}

1. Nabholtz JM, Reese DM, Lindsay MA and Riva A: Combination chemotherapy for metastatic breast cancer. Expert Rev Anticancer Ther 2: 169-180, 2002.

2. Zhao J, Kim JE, Reed E and Li QQ: Molecular mechanism of antitumor activity of taxanes in lung cancer (Review). Int J Oncol 27: 247-256, 2005.

3. Comin-Anduix B, Agell N, Bachs O, Ovadi J and Cascante M: A new bis-indole, KARs, induces selective $M$ arrest with specific spindle aberration in neuroblastoma cell line SH-SY5Y. Mol Pharmacol 60: 1235-1242, 2001.

4. Cassinelli G, Lanzi C, Supino R, Pratesi G, Zuco V, Laccabue D, Cuccuru G, Bombardelli E and Zunino F: Cellular bases of the antitumor activity of the novel taxane IDN 5109 (BAY59-8862) on hormone-refractory prostate cancer. Clin Cancer Res 8: 2647-2654, 2002.

5. Rowinsky EK and Donehower RC: Paclitaxel (taxol). N Engl J Med 332: 1004-1014, 1995.

6. Crown J and O'Leary M: The taxanes: an update. Lancet 355 : 1176-1178, 2000.

7. Vogel CL and Nabholtz JM: Monotherapy of metastatic breast cancer: a review of newer agents. Oncologist 4: 17-33, 1999.

8. Gligorov J and Lotz JP: Preclinical pharmacology of the taxanes: implications of the differences. Oncologist 9 (suppl 2): 3-8, 2004.

9. Ramalingam S and Belani CP: Taxanes for advanced non-small cell lung cancer. Expert Opin Pharmacother 3: 1693-1709, 2002.

10. Yang H, Wang $X$ and Yu L: The antitumor activity of elemene is associated with apoptosis. Zhonghua Zhong Liu Za Zhi 18: 169-172, 1996.

11. Tan P, Zhong W and Cai W: Clinical study on treatment of 40 cases of malignant brain tumor by elemene emulsion injection. Zhongguo Zhong Xi Yi Jie He Za Zhi 20: 645-648, 2000.

12. Wang J, Zhang H and Sun Y: Phase III clinical trial of elemenum emulsion in the management of malignant pleural and peritoneal effusions. Zhonghua Zhong Liu Za Zhi 18: 464-467, 1996.

13. Zhou HY, Shen JK, Hou JS, Qiu YM and Luo QZ: Experimental study on apoptosis induced by elemene in glioma cells. Ai Zheng 22: 959-963, 2003.

14. Wang XS, Yang W, Tao SJ, Li K, Li M, Dong JH and Wang MW: Effect of delta-elemene on Hela cell lines by apoptosis induction. Yakugaku Zasshi 126: 979-990, 2006.

15. Zou L, Liu W and Yu L: beta-elemene induces apoptosis of K562 leukemia cells. Zhonghua Zhong Liu Za Zhi 23: 196-198, 2001.

16. Zhou HY, Hou JS and Wang Y: Dose-and time-dependence of elemene in the induction of apoptosis in two glioma cell lines. Zhonghua Zhong Liu Za Zhi 28: 270-271, 2006.

17. Xu YH, Dong B, Luo QZ, Zhou HY, Jia YC, Yang YF and Wang YZ: Influence of elemene on the expression of Bcl-2 family genes in rat C6 glioma cells. Zhonghua Yi Xue Za Zhi 85: 1700-1703, 2005.

18. Wang G, Li X, Huang F, Zhao J, Ding H, Cunningham C, Coad JE, Flynn DC, Reed E and Li QQ: Antitumor effect of beta-elemene in non-small-cell lung cancer cells is mediated via induction of cell cycle arrest and apoptotic cell death. Cell Mol Life Sci 62: 881-893, 2005.

19. Li X, Wang G, Zhao J, Ding H, Cunningham C, Chen F, Flynn DC, Reed E and Li QQ: Antiproliferative effect of betaelemene in chemoresistant ovarian carcinoma cells is mediated through arrest of the cell cycle at the G2-M phase. Cell Mol Life Sci 62: 894-904, 2005.
20. Eminel S, Klettner A, Roemer L, Herdegen T and Waetzig V: JNK2 translocates to the mitochondria and mediates cytochrome c release in PC12 cells in response to 6-hydroxydopamine. J Biol Chem 279: 55385-55392, 2004.

21. Chou TC and Talalay P: Quantitative analysis of dose-effect relationships: the combined effects of multiple drugs or enzyme inhibitors. Adv Enzyme Regul 22: 27-55, 1984.

22. Martin T, Ochou OG, Vaissayre M and Fournier D: Organophosphorus insecticides synergize pyrethroids in the resistant strain of cotton bollworm, Helicoverpa armigera (Hubner) (Lepidoptera: Noctuidae) from West Africa. J Econ Entomol 96: 468-474, 2003.

23. Soriano AF, Helfrich B, Chan DC, Heasley LE, Bunn PA Jr and Chou TC: Synergistic effects of new chemopreventive agents and conventional cytotoxic agents against human lung cancer cell lines. Cancer Res 59: 6178-6184, 1999.

24. Salvesen GS and Dixit VM: Caspases: intracellular signaling by proteolysis. Cell 91: 443-446, 1997.

25. Wang GQ, Gastman BR, Wieckowski E, Goldstein LA, Rabinovitz A, Yin XM and Rabinowich H: Apoptosis-resistant mitochondria in T cells selected for resistance to Fas signaling. $\mathrm{J}$ Biol Chem 276: 3610-3619, 2001.

26. Bhalla K, Ibrado AM, Tourkina E, Tang C, Mahoney ME and Huang Y: Taxol induces internucleosomal DNA fragmentation associated with programmed cell death in human myeloid leukemia cells. Leukemia 7: 563-568, 1993.

27. Gangemi RM, Tiso M, Marchetti C, Severi AB and Fabbi M: Taxol cytotoxicity on human leukemia cell lines is a function of their susceptibility to programmed cell death. Cancer Chemother Pharmacol 36: 385-392, 1995.

28. Tao L, Zhou L, Zheng L and Yao M: Elemene displays anticancer ability on laryngeal cancer cells in vitro and in vivo. Cancer Chemother Pharmacol 58: 24-34, 2006.

29. Hu J, Jin W and Yang PM: Reversal of resistance to adriamycin in human breast cancer cell line MCF-7/ADM by beta-elemene. Zhonghua Zhong Liu Za Zhi 26: 268-270, 2004.

30. Yuan J, Gu ZL, Chou WH and Kwok CY: Elemene induces apoptosis and regulates expression of bcl-2 protein in human leukemia K562 cells. Zhongguo Yao Li Xue Bao 20: 103-106, 1999.

31. Budman DR and Calabro A: In vitro search for synergy and antagonism: evaluation of docetaxel combinations in breast cancer cell lines. Breast Cancer Res Treat 74: 41-46, 2002.

32. Miller B, Potter-Locher F, Seelbach A, Stopper H, Utesch D and Madle $\mathrm{S}$ : Evaluation of the in vitro micronucleus test as an alternative to the in vitro chromosomal aberration assay: position of the GUM Working Group on the in vitro micronucleus test. Gesellschaft fur Umwelt-Mutations-forschung. Mutat Res 410: 81-116, 1998.

33. Huisman C, Ferreira CG, Broker LE, Rodriguez JA, Smit EF, Postmus PE, Kruyt FA and Giaccone G: Paclitaxel triggers cell death primarily via caspase-independent routes in the non-small cell lung cancer cell line NCI-H460. Clin Cancer Res 8: 596-606, 2002.

34. Daniel PT, Wieder T, Sturm I and Schulze-Osthoff K: The kiss of death: promises and failures of death receptors and ligands in cancer therapy. Leukemia 15: 1022-1032, 2001.

35. Los M, Wesselborg S and Schulze-Osthoff K: The role of caspases in development, immunity, and apoptotic signal transduction: lessons from knockout mice. Immunity 10: 629-639, 1999.

36. von Haefen C, Wieder T, Essmann F, Schulze-Osthoff K, Dorken B and Daniel PT: Paclitaxel-induced apoptosis in BJAB cells proceeds via a death receptor-independent, caspases-3/-8driven mitochondrial amplification loop. Oncogene 22: 2236-2247, 2003.

37. Ferreira CG, Tolis C, Span SW, Peters GJ, van Lopik T, Kummer AJ, Pinedo HM and Giaccone G: Drug-induced apoptosis in lung cancer cells is not mediated by the Fas/FasL (CD95/APO1) signaling pathway. Clin Cancer Res 6: 203-212, 2000.

38. Wieder T, Essmann F, Prokop A, Schmelz K, Schulze-Osthoff K, Beyaert R, Dorken B and Daniel PT: Activation of caspase- 8 in drug-induced apoptosis of B-lymphoid cells is independent of CD95/Fas receptor-ligand interaction and occurs downstream of caspase-3. Blood 97: 1378-1387, 2001.

39. Pirnia F, Schneider E, Betticher DC and Borner MM: Mitomycin $\mathrm{C}$ induces apoptosis and caspase- 8 and -9 processing through a caspase-3 and Fas-independent pathway. Cell Death Differ 9: 905-914, 2002. 
40. Bacso Z, Everson RB and Eliason JF: The DNA of annexin Vbinding apoptotic cells is highly fragmented. Cancer Res 60 : 4623-4628, 2000

41. Schimming R, Mason KA, Hunter N, Weil M, Kishi K and Milas L: Lack of correlation between mitotic arrest or apoptosis and antitumor effect of docetaxel. Cancer Chemother Pharmacol 43: 165-172, 1999.

42. Bacus SS, Gudkov AV, Lowe M, Lyass L, Yung Y, Komarov AP, Keyomarsi K, Yarden Y and Seger R: Taxol-induced apoptosis depends on MAP kinase pathways (ERK and p38) and is independent of p53. Oncogene 20: 147-155, 2001.

43. Das GC, Holiday D, Gallardo R and Haas C: Taxol-induced cell cycle arrest and apoptosis: dose-response relationship in lung cancer cells of different wild-type p53 status and under isogenic condition. Cancer Lett 165: 147-153, 2001.

44. Yoo GH, Piechocki MP, Ensley JF, Nguyen T, Oliver J, Meng H, Kewson D, Shibuya TY, Lonardo F and Tainsky MA: Docetaxel induced gene expression patterns in head and neck squamous cell carcinoma using cDNA microarray and PowerBlot. Clin Cancer Res 8: 3910-3921, 2002.
45. Martello LA, Verdier-Pinard P, Shen HJ, He L, Torres K, Orr GA and Horwitz SB: Elevated levels of microtubule destabilizing factors in a Taxol-resistant/dependent A549 cell line with an alpha-tubulin mutation. Cancer Res 63: 1207-1213, 2003.

46. Ibrado AM, Huang Y, Fang G and Bhalla K: Bcl-xL overexpression inhibits taxol-induced Yama protease activity and apoptosis. Cell Growth Differ 7: 1087-1094, 1996.

47. Huang Y, Ibrado AM, Reed JC, Bullock G, Ray S, Tang C and Bhalla K: Co-expression of several molecular mechanisms of multidrug resistance and their significance for paclitaxel cytotoxicity in human AML HL-60 cells. Leukemia 11: 253-257, 1997.

48. Simoes-Wust AP, Schurpf T, Hall J, Stahel RA and Zangemeister-Wittke U: Bcl-2/bcl-xL bispecific antisense treatment sensitizes breast carcinoma cells to doxorubicin, paclitaxel and cyclophosphamide. Breast Cancer Res Treat 76: 157-166, 2002.

49. Lee HC and Wei YH: Mitochondrial role in life and death of the cell. J Biomed Sci 7: 2-15, 2000. 